\title{
THE EFFECTIVENESS OF A TRAINING COURSES FOR Developing the Productive Capacities in the fleld of FOOD INDUSTRIES FOR THE WOMEN AND GIRLS IN REFA aNd Albadary VILlages IN ASSIUt gOVERnORATE, tO SERVE THE SMALL PROJECTS
}

In Partial Requirements

The Project for the Master Plan Study for Rural Development through Improving Marketing of Agricultural Produce for Small Scale Farmers in

Upper Egypt (IMAP)

By

Dr. Nareman Saed Eshak Bahna

Lecturer - the Department of Home Economics

(specializing in Nutrition and Food Science)

Faculty of Specific Education - Assiut University

\section{Research Joupnal Specific Education \\ Faculty of Specific Education \\ Mansoura University}

ISSUE NO. 25, APRIL. 2012

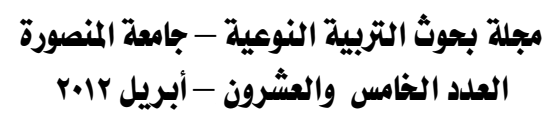


The Effectiveness of a Training Courses for Developing the Productive Capacities 


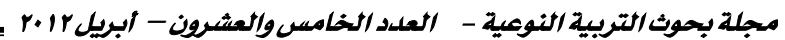

\title{
The EfFEctiveness of a TRAINIng COURSES fOR DeVEloping THE PROdUCtIVE CAPACITIES IN THE fIELD Of FOOD INDUSTRIES FOR THE WOMEN AND GIRLS IN REFA AND ALBADARY VILLAGES in Assivt governorate, to serve the SMall Projects
}

\author{
Dr. Nareman Saed Eshak Bahna*
}

\section{Abstract}

Aim: Evaluating the effectiveness of training courses for developing the productive capacities in the field of Food Industries for the women and girls in Refa and Albadary villages at Assiut governorate, to serve the small projects.

Individuals\& Methods: 36 women and girls from Refa and Albadary villages in Assiut governorate. Their ages from (20-35yrs), 18 women at Refa village and 18 at Albadary village. The trainees were divided every village into three equal groups so that each trainee be seen knock a good product implementation (each group consists of 6 members). All trainees were subjected to socioeconomic data (age, education level, occupation, family size, number of home equipments) and aspects of knowledge and skill tests pre and post the training courses. The researcher in collaboration with JICA study team Council for SANYU CONSULTANTS INC. Japanese to Project for the Master Plan Study for Rural Development through Improving Marketing of Agricultural Produce for Small Scale Farmers in Upper Egypt (IMP) has lectured on the theory of the trainees to study of the small projects including: definition - their properties - kinds elements - dimensions - characteristics - and their role in the development. Besides study of training including definition - objectives and importance planning principals for educational studies - stages of evaluation. Also, the research theoretical framework of training courses comprised Jams, juices, fruits, and vegetables study: definition - kinds - signs and features of quality - the properties of virtual and internal - nutrient content - ideal storage - seasons and methods of implementation - kinds of and reasons of disadvantages and invalidity- considerations of industrial and commercial quality.While in the practical side of training courses has the researcher

* Lecturer - the Department of Home Economics (specializing in Nutrition and Food Science) Faculty of Specific Education - Assiut University 
explained the detailed practical methods of manufacture of fig, carrot, and orange jam, pomegranate and orange juice, ways of keeping okra, pomegranates by freezing, and processing of tomato sauce, The trainees in each village were divided to three equally groups so that each trainee practice good product is required. The researcher followed the experimental way. These training courses have been implemented in a place designated a training Agricultural of the Association for each village, this place is prepared under the supervision of a researcher in collaboration with the JICA study team. Practical training for each product was carried out three times (time for each group) for four hours/ day. Statistical analyses were applied.

Results: revealed that the effectiveness of training courses for developing the productive capacities in the field of Food Industries for the women and girls in Refa and Albadary villages at Assiut governorate, to serve the small projects. And improve the gained knowledge and skills to the trainees after the training courses.

This research was carried out to study the effect of addition volatile oils from natural herbs namely ginger, clove and peppermint on prolonging the shelf life of cold minced meat . Commercial raw minced beef meat was treated with extracted volatile oils at concentration of $1 \%$ and stored at 3$5^{\circ} \mathrm{C}$ for 10 days. Results of GC-MASS indicated that all extracted volatile oils from herbs under investigation contained a various amount of aromatic compounds, namely oxygenated, terpens, alcohols, esters and phenols, The most effective radical scavenging activity DPPH was detected in clove oil was $85.72 \%$ in compare with the added volatile oils. Color, $\mathrm{pH}$, Total Volatile Basis Nitrogen (TVB-N) and Thiobarbituric Acid Value (TBA) were determined..The meat beef samples treated with $1 \%$ (ginger oil + clove oil + peppermint oils ) showed the best colour, $\mathrm{pH}$, lowering protein hydrolysis and reducing lipid oxidation, prolonged storage period in compare with other treated minced beef meat and control samples. Total Bacterial Count (TBC) was decreased in beef meat samples treated with essential oils than those of the control meat. All samples showed good overall acceptability and still accepted for sensory properties up to 8 days of storage at $3-5^{\circ} \mathrm{C}$.

The obtained results indicated that aromatic compounds presented in volatile oils have high antioxidative effect in reducing the formation of secondary oxidation products and formation of ammonia during cold storage. So, It can be concluded that theses natural oils have potential effect to replace synthetic antioxidants which used in meat processing. 


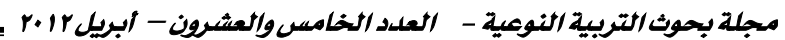

\title{
The effactiveness of a Training CoURSes for DeVEloping the Productive Capacities IN THE fIELD Of FOOd INDUSTRIES FOR THE WOMEN AND GIRLS IN REFA AND ALBADARY VILLAGES in Assivt governorate, to serve the SMall Projects
}

\author{
Dr. Nareman Saed Eshak Bahna*
}

\section{Introduction:}

The history of small industries in Egypt to the oldest ages since ancient Egyptian times and even now passing era Greco-Roman, Coptic and Islamic world, where these industries have played an important role in the provision of basic needs and different to the Egyptians (Fathi Z., 2006).

A small-scale industries play an important role in the national economy of many advanced and developing countries and the economic and social analysis indicate the development of international experience in this field but some Asian countries have made tremendous achievements during the last two decades and turned from the forces of consumer power to be productive creative resort to the small producer and small industries that fit with their own investments, through the exploitation of raw materials available and devise new methods of implementation consistent with the abundance of labor to produce goods linked to the daily lives of citizens like food and textiles industries (Richard J.,2000 \& Ibrahim H., 2005). As a result of increased awareness of the state of the importance of small industries in advancing economic development and wealth of the passage of positive social began to adopt economic policies, legislative and manufacturing that will demand the youth to establish small businesses and as a result of the number of small projects increased as a cornerstone in the economic structure and through the preparation of technical staff trained (Abdel Aziz R., 2001).

Training is the voltage regulator planned which aims to provide workers with the knowledge, skills and new behavioral patterns as well as their knowledge, skills, and modifies their behavior patterns at work (Alselmy, 1992).

* Lecturer - the Department of Home Economics (specializing in Nutrition and Food

Science) Faculty of Specific Education - Assiut University 
The jam of the methods of keeping fruit turning to food products not subject to corruption. And known to jam housewives Therefore Valojthad Profile play an important role in their production. Indeed, industrial production is no different from their production at home, but shorten the cooking time even to the least extent possible so as not to be affected by the color or taste or nutritional value as a result of the temperature in the resort industry to clean industrial products added instead of adding natural materials like the addition of citric acid instead of lemon juice. Jam is a mixture consisting mainly of sugar, fruits, whole or fragmented, or mashed, which is not less than the proportion of fruit used in the industry for 45 parts by weight of sugar and 55 parts by weight (Lang\& Jenifer H., 1998).

Fruit juice is a drink of fruit and make juice from fresh fruit that we get squeezing fruit and filter the juice and save transaction thermal where is poured in a special container shall be boiled for a short period and during that add to it a sufficient quantity and appropriate when it was melting the amount of sugar taken the juice boiled and cooled and filtered by filters and packed in special containers or bottles especially.

The process of freezing food is to rid this article from the heat and give this heat to another substance and the delivery of food material to be saved to a temperature low does not allow active growth and multiplication factors of corruption of bacteria, fungi and yeasts do not allow active enzymes or other chemical reactions. The idea industry of tomato sauce concentration on the sauce solids to about $25 \%$ and add salt and preservative and color turned to dark red (Hussein T., 2007).

From this the researcher in terms of specialization as a member of the faculty in the field of Nutrition and Food Science in thinking about ways to use food processing through the preparing of training courses in this field for a group of women Rifa and Albadary villages of Assiut Governorate in collaboration with JICA study team Council for SANYU CONSULTANTS INC. Japanese.

The present study aimed to evaluate the effectiveness of training courses for developing the productive capacities in the field of food industries for the women and girls in Refa and Albadary villages at Assiut governorate, to serve the small projects. Also, aappreciation for the sensory attributes of quality products for consumers. 


\section{Individuals and Methods:}

Individuals: The study was conducted on 36 women and girls trainees from Refa and Albadary villages in Assiut governorate. Their ages from (20-35yrs), 18 women and girls at Refa village and 18 at Albadary village. The trainees were divided of each village into three equal groups so that each trainee is seen knock a good product implementation (each group consists of 6 members). All trainees were subjected to socioeconomic data including (age, education level, occupation, family size, number of home equipments) and aspects of knowledge and skill tests pre and post the training courses.

\section{Methods:}

The researcher in collaboration with the JICA study team Japanese held interviews and discussions with the staff of the agricultural societies of each village to identify the distinctive crop of every village and find the surplus in the season.

The researcher talked about the study of the small projects to the trainees including: definition - their properties - kinds - elements - dimensions characteristics - and their role in the development. Besides study of training including definition - objectives and importance - planning principals for educational.

Also, the researcher has lectured on the theory of the trainees to explain Jams, juices, fruits, and vegetables in terms of ( definition - kinds - signs and features of quality - the properties of virtual and internal - nutrient content - ideal storage - seasons and methods of implementation - kinds of and reasons of disadvantages and invalidity - considerations of industrial and commercial quality. The researcher explained and the implementation of the every product according to (Gomaa E., 2007) to each group once and then the trainees implemented alone in next time, and so the following two groups in each village. This study included these food products (figs and orange jam, orange and pomegranate juice, and freezing pomegranate) in Albadary village, and (fig and carrot jam, freezing okra, and tomato sauce) in Refa village. This choice was because of the availability of these agricultural products and increases the surplus in the season in every village. These training courses have been implemented in a place designated a training Agricultural of the Association for each village, this place is prepared under the supervision of a researcher in collaboration with the JICA study team. Practical training for each product was carried out three times (time for each group) for four hours/ day. In the end after the making 
The Effectiveness of a Training Courses for Developing the Productive Capacities

of food products have been evaluated of the sensory evaluation by 30 consumers.

- The researcher followed the experimental way. Statistical analysis were performed using IBM-PC computer; statistical package software SPSS windows. Analysis of variance (ANOVA one way) was applied in this study for comparison among mean, of different groups, (Vandallen, 1994).

\section{Results:}

Table (1): Represents the mean age of trainees was 27.5 years. Education level was $69.4 \%$ of trainees whose education level secondary, followed by $25.00 \%$ and $5.55 \% \%$ of trainees were having high and basic but nobody of trainees illiterate. Also, $11.11 \%$ of trainees work, while $88.05 \%$ was housewives. It was $19.44 \%$ of trainees have $<4$ persons in family and $80.55 \%$ have $>4$ persons in family. According to social status, $58.33 \%$ of trainees whose social status were single, and $41.67 \%$ were married, while no body of trainees were widow, and divorcee. Regarding district, all the trainees live in rural districts. According to the number of home equipments, $92.0 \%$ of trainees had $\leq 7$ basic home equipments and $8.00 \%$ $\operatorname{had}>7$. 


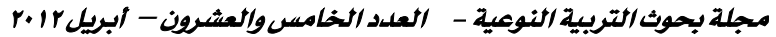

Table (1): Socio - Economic and Demographic Data of the Trainees Women and Girls $(\mathrm{n}=36$

\begin{tabular}{|c|c|c|c|c|}
\hline & Items & Description & Chi-square & Asymp.sig \\
\hline 1 & $\begin{array}{l}\text { Age (yrs) } \\
\text { mean } \pm \text { S.D } \\
(\text { min-mix })\end{array}$ & $\begin{array}{c}27.5 \pm 7.5 \\
(20-35)\end{array}$ & & \\
\hline 2 & $\begin{array}{c}\text { Education level } \\
\text { - Illiterate } \\
\text {-basic } \\
\text {-secondary } \\
\text {-high } \\
\end{array}$ & $\begin{array}{c}-\overline{2}(\overline{5.55 \%} \%) \\
25(69.4 \%) \\
9(25.00 \%)\end{array}$ & 23.167 & 0.001 \\
\hline 3 & $\begin{array}{l}\text { Occupation } \\
\text {-work } \\
\text {-housewife }\end{array}$ & $\begin{array}{c}4(11.11 \%) \\
32(88.89 \%)\end{array}$ & 21.778 & 0.001 \\
\hline 4 & $\begin{array}{c}\text { Family Size } \\
-<4 \\
->4 \\
\end{array}$ & $\begin{array}{c}7(19.44 \%) \\
29(80.55 \%)\end{array}$ & 13.444 & 0.001 \\
\hline 5 & $\begin{array}{c}\text { Social Status:- } \\
\text { - Single } \\
\text {-married } \\
\text {-widow } \\
\text { - divorcee }\end{array}$ & $\begin{array}{c}21(58.33 \%) \\
15(41.67 \%) \\
-\end{array}$ & 1.000 & N.S. \\
\hline 6 & $\begin{array}{l}\text { District } \\
\text {-Urban } \\
\text { - rural } \\
\end{array}$ & $\overline{36(100 \%)}$ & 32.111 & 0.001 \\
\hline 7 & $\begin{array}{c}\text { Number of home } \\
\text { equipments } \\
-\leq \text { basic }(7) \\
->7\end{array}$ & $\begin{array}{c}33(92.0 \%) \\
8.00 \%)(3\end{array}$ & 25.000 & 0.001 \\
\hline
\end{tabular}

Table (2): Illustrates that the highest percentage of trainees didn't know the methods of manufacture jams pre training courses $(86.11 \%)$ followed by $(83.33 \%, 83.33 \%, 88.89 \%)$ respectively don't know the methods of manufacture juices, keeping fruit and vegetables freezing and manufacture of tomato sauce. While post training courses, it could be seen that the highest percentage of trainees were knowing the methods of manufacture jams $(97.22 \%)$ and $(100 \%)$ know the methods of manufacture juices, keeping fruit and vegetables freezing and manufacture of tomato sauce. 
The Effectiveness of a Training Courses for Developing the Productive Capacities

Table (2): Comparison the Cognitive Aspects to the Women and Girls Trainees Pre and Post the Training Courses:

\begin{tabular}{|c|c|c|c|c|c|c|c|c|}
\hline \multirow[b]{2}{*}{ Items } & \multicolumn{3}{|c|}{ pre } & \multicolumn{3}{|c|}{ Post } & \multirow{2}{*}{ 㿿 } & \multirow{2}{*}{ ra } \\
\hline & $\begin{array}{c}\text { Yes } \\
\mathbf{N}=36\end{array}$ & $\begin{array}{c}\text { No } \\
n=36\end{array}$ & $\begin{array}{c}\begin{array}{c}\text { To some } \\
\text { extent } \\
n=36\end{array} \\
\end{array}$ & $\underset{n=36}{Y e s}$ & $\begin{array}{c}\text { No } \\
n=36\end{array}$ & $\begin{array}{c}\begin{array}{c}\text { To some } \\
\text { extent } \\
n=36\end{array} \\
\end{array}$ & & \\
\hline \begin{tabular}{|c|} 
1- Knowing the \\
trainees methods \\
of manufacture \\
jams
\end{tabular} & $\begin{array}{c}3 \\
(8.33 \%)\end{array}$ & $\begin{array}{c}31 \\
(86.11 \%)\end{array}$ & $\begin{array}{c}2 \\
(5.56 \%)\end{array}$ & $35(97.22 \%)$ & - & $1(2.78 \%)$ & 17.397 & 0.001 \\
\hline $\begin{array}{c}\text { 2- Knowing the } \\
\text { trainees methods } \\
\text { of manufacture } \\
\text { juices }\end{array}$ & $\mid 5(13.89 \%)$ & $\begin{array}{c}30 \\
(83.33 \%)\end{array}$ & $\begin{array}{c}1 \\
(2.78 \%)\end{array}$ & $36(100 \%)$ & - & - & 14.321 & 0.001 \\
\hline \begin{tabular}{|c|} 
3- Knowing the \\
trainees methods \\
of keeping fruits \\
and vegetables \\
freezing
\end{tabular} & $4(11.11 \%)$ & $\begin{array}{c}30 \\
(83.33 \%)\end{array}$ & $\begin{array}{c}2 \\
(5.56 \%)\end{array}$ & $36(100 \%)$ & - & - & 15.669 & 0.001 \\
\hline \begin{tabular}{|c|} 
4- Knowing the \\
trainees methods \\
of manufacture of \\
tomato sauce
\end{tabular} & - & $\begin{array}{c}32 \\
(88.89 \%)\end{array}$ & $\begin{array}{c}4 \\
(11.11 \%\end{array}$ & $36(100 \%)$ & - & - & 35.558 & 0.001 \\
\hline
\end{tabular}

Table (3): represents comparison the aspects of skill to the women and girl trainees' pre and post the training courses. The highest percentage of trainees $(94.44 \%)$ using ready- made jam pre training courses, and (5.56\%) using ready-made jam to some extent. While post training courses, $(58.33 \%)$ of trainees using ready- made jam to some extent and (13.8\%) using ready- made jam and $(27.78 \%)$ didn't use ready-made jam. 
Table (3): Comparison the Aspects of Skill to the Women and Girls Trainees Pre and Post the Training Courses:

\begin{tabular}{|c|c|c|c|c|c|c|c|c|}
\hline \multirow[b]{2}{*}{ Items } & \multicolumn{3}{|c|}{ pre } & \multicolumn{3}{|c|}{ post } & \multirow[b]{2}{*}{ 島 } & \multirow[b]{2}{*}{ ब. } \\
\hline & $\begin{array}{c}\text { Yes } \\
\mathbf{N}=36\end{array}$ & $\begin{array}{c}\text { No } \\
\mathbf{N}=36\end{array}$ & $\begin{array}{c}\text { To some } \\
\text { extent } \\
\mathrm{N}=36\end{array}$ & $\begin{array}{c}\text { Yes } \\
\mathbf{n}=36\end{array}$ & No $n=36$ & $\begin{array}{c}\text { To some extent } \\
n=36\end{array}$ & & \\
\hline $\begin{array}{l}\text { 1-Using ready- } \\
\text { made jams }\end{array}$ & $34(94.44 \%)$ & - & $2(5.56 \%)$ & $5(13.89 \%)$ & $10(27.78 \%)$ & $21(58.33 \%)$ & $|10.769|$ & 0.001 \\
\hline $\begin{array}{l}\text { 2- Using ready- } \\
\text { made juice }\end{array}$ & $23(63.89 \%)$ & $7(19.44 \%)$ & $6(16.67 \%)$ & $12(33.33 \%)$ & $20(55.55 \%)$ & $3(8.33 \%)$ & 5.045 & 0.01 \\
\hline $\begin{array}{l}\text { 3- Using ready- } \\
\text { made vvegetables } \\
\text { and fruits frozen }\end{array}$ & $2(5.56 \%)$ & $30(83.3 \%)$ & $4(11.11 \%)$ & - & $35(97.22 \%)$ & $1(2.78 \%)$ & 2.497 & 0.05 \\
\hline $\begin{array}{l}\text { 4- Using ready- } \\
\text { made tomato sauce }\end{array}$ & $10(27.78 \%)$ & $\mid 12(33.3 \%)$ & $14(38.89 \%)$ & $2(5.56 \%)$ & $22(61.11 \%)$ & $12(33.33 \%)$ & 5.918 & 0.01 \\
\hline $\begin{array}{c}\text { 5- Making a jam in } \\
\text { her home }\end{array}$ & $3(8.33 \%)$ & $30(83.3 \%)$ & $3(8.33 \%)$ & $28(77.77 \%)$ & $2(5.56 \%)$ & $6(16.67 \%)$ & 11.998 & 0.001 \\
\hline $\begin{array}{l}\text { 6- Making fresh } \\
\text { juices in her home }\end{array}$ & $6(16.67 \%)$ & $\begin{array}{c}25(69.44 \% \\
)\end{array}$ & $5(13.89 \%)$ & $29(80.55 \%)$ & $3(8.33 \%)$ & $4(11.11 \%)$ & 8.919 & 0.001 \\
\hline $\begin{array}{c}\text { 7- Saving the } \\
\text { vegetables and } \\
\text { fruits by freezing } \\
\text { method } \\
\end{array}$ & $1(2.78 \%)$ & $35(97.2 \%)$ & - & $28(77.77 \%)$ & $3(8.33 \%)$ & $5(13.89 \%)$ & 14.407 & 0.001 \\
\hline $\begin{array}{l}\text { 8- Making tomato } \\
\text { sauce in her home }\end{array}$ & $3(8.33 \%)$ & $32(88.8 \%)$ & $1(2.78 \%)$ & $30(83.33 \%)$ & $2(5.56 \%)$ & $4(11.11 \%)$ & 12.979 & 0.001 \\
\hline
\end{tabular}

According to using ready-made juice, it could be seen that $(63.89 \%)$ using ready made juice pre training courses, while $(55.55 \%)$ didn't use readymade juice post training courses.

Regarding using ready-made vegetables and fruits frozen, it could be noticed that $(83.3 \%)$ of trainees didn't use ready-made vegetables and fruits frozen pre training courses, while $(97.22 \%)$ didn't use ready-made vegetables and fruits frozen post training courses.

Concerning using ready-made tomato sauce, it could be seen that (38.89\%) of trainees use ready-made tomato sauce to some extent pre training courses, but post training courses $(61.11 \%)$ of trainees were not use ready-made tomato sauce.

Regarding making a jam in her home, it was clear that (83.3\%) of trainees didn't make a jam in their home pre training courses, while $(77.77 \%)$ of trainees making a jam in their home post training courses. According to making fresh juices, it be noticed that $(69.44 \%)$ of trainees didn't make fresh juice pre training courses, but (80.55\%) make fresh juice post training courses. Concerning making tomato sauce, it was clear that $(88.8 \%)$ of trainees pre training courses were not make tomato sauce, while 
post training courses were $(83.3 \%)$ making tomato sauce. Dealing with saving the vegetables and fruits by freezing method, it could be seen that $(97.2 \%)$ of trainees were not saving the vegetables and fruits by freezing method pre training courses, but $(77.77 \%)$ post training courses were saving the vegetables and fruits by freezing method.

Table (4): Shows sensory evaluation for the consumers of the quality attributes of a food product fig jam made from the trainees after the training courses. It could be seen that $(70.0 \%)$ of the consumers evaluated the general appearance of fig jam that is acceptable, and (30.0\%) of the consumers very acceptable, while $(90.0 \%)$ of the consumers evaluated the taste that is very desirable. Dealing with the smell, $(90.0 \%)$ of the consumers found the smell is strong. Concerning the textures was somewhat coherent by $(96.67 \%)$ of the consumers. According to the color was matched with the color of the fruit used by $(83.33 \%)$ of the consumers. The period of validity was evaluated such as product-ready by $(100 \%)$ of the consumers. 
مجلة بحوث التربية النوعية - العلدد الخامس والعشرون - أبريل r r r r r

Table (4): Sensory evaluation for the consumers of the quality attributes of a food product (Fig jam) made from the trainees after the training courses:

\begin{tabular}{|c|c|c|c|c|c|}
\hline \multirow{3}{*}{\begin{tabular}{|c|c|}
$\begin{array}{c}\text { The } \\
\text { Product }\end{array}$ \\
Fig Jam
\end{tabular}} & \multicolumn{3}{|c|}{ Evaluation Description } & \multirow{2}{*}{$\begin{array}{c}\text { Mean } \\
\text { standard }\end{array}$} & \multirow{2}{*}{$\begin{array}{c}\text { Mean } \\
\text { answer }\end{array}$} \\
\hline & & & $\mathbf{N}=\mathbf{3 0}$ & & \\
\hline & \multirow{4}{*}{\begin{tabular}{|l|} 
General \\
appearance
\end{tabular}} & Very acceptable & 9(30,0\%) & \multirow{4}{*}{2.50} & \multirow{4}{*}{$\begin{array}{c}3.30 \\
\text { Acceptable }\end{array}$} \\
\hline & & Acceptable & $21(70.0 \%)$ & & \\
\hline & & Acceptable to some extent & - & & \\
\hline & & Unacceptable & - & & \\
\hline & \multirow[t]{3}{*}{ Taste } & Very desirable & $27(90 \%)$ & \multirow{3}{*}{2.00} & \multirow{3}{*}{$\begin{array}{c}2.90 \\
\text { Very } \\
\text { desirable }\end{array}$} \\
\hline & & Desirable & $3(10.0 \%)$ & & \\
\hline & & Not desirable & - & & \\
\hline & \multirow[t]{3}{*}{ Smell } & Weak & - & \multirow[t]{3}{*}{2.00} & \multirow{3}{*}{$\begin{array}{l}1.10 \\
\text { Strong }\end{array}$} \\
\hline & & Average & $3(10.0 \%)$ & & \\
\hline & & Strong & $27(90.0 \%)$ & & \\
\hline & \multirow[t]{3}{*}{ Textures } & Solid & $1(3.33 \%)$ & \multirow[t]{3}{*}{2.00} & \multirow{3}{*}{$\begin{array}{c}2.30 \\
\text { Somewhat } \\
\text { coherent }\end{array}$} \\
\hline & & Somewhat coherent & $29(96.67 \%)$ & & \\
\hline & & Soft & - & & \\
\hline & \multirow{3}{*}{ Color } & Light & $2(6.67 \%)$ & \multirow[t]{3}{*}{2.00} & \multirow{3}{*}{$\begin{array}{c}1.97 \\
\text { Matched } \\
\text { with the } \\
\text { color of the } \\
\text { fruit used }\end{array}$} \\
\hline & & $\begin{array}{l}\text { Matched with the color of } \\
\text { the fruit used }\end{array}$ & $25(83.33 \%)$ & & \\
\hline & & Dark & $3(10.0 \%)$ & & \\
\hline & \multirow{3}{*}{$\begin{array}{l}\text { The period } \\
\text { of validity }\end{array}$} & Such as product-ready & $30(100 \%)$ & \multirow[t]{3}{*}{2.00} & \multirow{3}{*}{$\begin{array}{c}3.00 \\
\text { Such as } \\
\text { product- } \\
\text { ready }\end{array}$} \\
\hline & & Less of the product-ready & - & & \\
\hline & & $\begin{array}{l}\text { Longer than the product- } \\
\text { ready }\end{array}$ & - & & \\
\hline
\end{tabular}


Table (5): Sensory evaluation for the consumers of the quality attributes of a food product (Carrot jam) made from the trainees after the training courses:

\begin{tabular}{|c|c|c|c|c|c|}
\hline \multirow{4}{*}{\begin{tabular}{|l} 
The Product \\
Carrot Jam
\end{tabular}} & \multicolumn{3}{|c|}{ Evaluation Description } & \multirow{2}{*}{$\begin{array}{c}\text { Mean } \\
\text { standard }\end{array}$} & \multirow{2}{*}{$\begin{array}{c}\text { Mean } \\
\text { answer }\end{array}$} \\
\hline & & & $\mathbf{N}=\mathbf{3 0}$ & & \\
\hline & \multirow{4}{*}{\begin{tabular}{|l|} 
General \\
appearance
\end{tabular}} & Very acceptable & $2(6.67 \%)$ & \multirow[t]{4}{*}{2.50} & \multirow{4}{*}{$\begin{array}{c}2.57 \\
\text { Acceptable }\end{array}$} \\
\hline & & Acceptable & $18(60,0 \%)$ & & \\
\hline & & $\begin{array}{l}\text { Acceptable to some } \\
\text { extent }\end{array}$ & $8(26.67 \%)$ & & \\
\hline & & Unacceptable & $2(6.67 \%)$ & & \\
\hline & \multirow[t]{3}{*}{ Taste } & Very desirable & $2(6.67 \%)$ & \multirow[t]{3}{*}{2.00} & \multirow{3}{*}{$\begin{array}{c}1.87 \\
\text { Desirable }\end{array}$} \\
\hline & & Desirable & $22(73.33 \%)$ & & \\
\hline & & Not desirable & $6(20.0 \%)$ & & \\
\hline & \multirow[t]{3}{*}{ Smell } & Weak & $2(6.67 \%)$ & \multirow[t]{3}{*}{2.00} & \multirow{3}{*}{$\begin{array}{l}1.33 \\
\text { Strong }\end{array}$} \\
\hline & & Average & $6(20.0 \%)$ & & \\
\hline & & Strong & $22(73.33 \%)$ & & \\
\hline & \multirow{3}{*}{ Textures } & Solid & $2(6.67 \%)$ & \multirow[t]{3}{*}{2.00} & \multirow{3}{*}{$\begin{array}{c}1.97 \\
\text { Somewhat } \\
\text { coherent }\end{array}$} \\
\hline & & Somewhat coherent & $25(83.33 \%)$ & & \\
\hline & & Soft & $3(10.0 \%)$ & & \\
\hline & \multirow{3}{*}{ Color } & Light & $5(16.67 \%)$ & \multirow[t]{3}{*}{2.00} & \multirow{3}{*}{$\begin{array}{c}2.07 \\
\text { Matched } \\
\text { with the } \\
\text { color of the } \\
\text { fruit used }\end{array}$} \\
\hline & & $\begin{array}{l}\text { Matched with the } \\
\text { color of the fruit used }\end{array}$ & $22(73.33 \%)$ & & \\
\hline & & Dark & $3(10.0 \%)$ & & \\
\hline & \multirow[t]{3}{*}{$\begin{array}{l}\text { The period } \\
\text { of validity }\end{array}$} & $\begin{array}{l}\text { Such as product- } \\
\text { ready }\end{array}$ & $30(100 \%)$ & \multirow[t]{3}{*}{2.00} & \multirow{3}{*}{$\begin{array}{c}3.00 \\
\text { Such as } \\
\text { product- } \\
\text { ready }\end{array}$} \\
\hline & & $\begin{array}{l}\text { Less of the product- } \\
\text { ready }\end{array}$ & - & & \\
\hline & & $\begin{array}{l}\text { Longer than the } \\
\text { product- ready }\end{array}$ & - & & \\
\hline
\end{tabular}

Table (5): Represents sensory evaluation for the consumers of the quality attributes of a food product carrot jam made from the trainees after the training courses. It was clear that the highest percentage of consumers $(60.0 \%)$ evaluated the general appearance for carrot jam that is acceptable. Dealing with the taste was found that $(73.3 \%)$ of consumers evaluated that is desirable. Regarding the smell was strong by $(73.33 \%)$ of the consumers. The textures was somewhat coherent by $(83.33 \%)$ of the consumers. Concerning the color was matched with the color of the fruit used by $(73.33 \%)$ of the consumers. Regarding the period of validity, it was clear that all consumers $(100 \%)$ evaluated that is such as product-ready. 
Table (6): Shows sensory evaluation for the consumers of the quality attributes of a food product orange jam made from the trainees after the training courses. It could be noticed that the general appearance is acceptable by $(53.33 \%)$ of the consumers and very acceptable by $(46.67 \%)$ of the consumers. According to the taste was very desirable by $(86.67 \%)$ of the consumers. Regarding the smell was strong by $(96.67 \%)$ of the consumers. Also, the texture was somewhat coherent by $(96.67 \%)$ of the consumers. Concerning the color was matched with color of the fruit used by $(83.33 \%)$ of the consumers. The period of the validity was such as product-ready by all of the consumers $(100 \%)$.

Table (7): Represents sensory evaluation for the consumers of the quality attributes of a food product ppomegranate juice made from the trainees after the training courses. It was clear that the general appearance was homogeneous by $(93.33 \%)$ of the consumers. $(86.67 \%)$ of the consumers evaluated the taste that is very desirable, while $(66.67 \%)$ of the consumers evaluated the smell that is strong. According to the phenomenon of leaching was didn't find by $(86.67 \%)$ of the consumers. Regarding the color was dark red by $(83.33 \%)$ of the consumers. The period of validity was less of the product ready by $(86.67 \%)$ of the consumers. 
Table (6): Sensory evaluation for the consumers of the quality attributes of a food product (Orange jam) made from the trainees after the training courses:

\begin{tabular}{|c|c|c|c|c|c|}
\hline \multirow{3}{*}{\begin{tabular}{|l|} 
The Product \\
Orange Jam
\end{tabular}} & \multicolumn{3}{|c|}{ "Evaluation Description } & \multirow[t]{2}{*}{ Mean standard } & \multirow{2}{*}{$\begin{array}{c}\text { Mean } \\
\text { answer }\end{array}$} \\
\hline & & & $\mathbf{N}=\mathbf{3 0}$ & & \\
\hline & \multirow[t]{4}{*}{\begin{tabular}{|l|} 
General \\
appearance
\end{tabular}} & Very acceptable & $14(46.67 \%)$ & \multirow[t]{4}{*}{2.50} & \multirow[t]{4}{*}{\begin{tabular}{|c|}
3.47 \\
Acceptable
\end{tabular}} \\
\hline & & Acceptable & $16(53.33 \%)$ & & \\
\hline & & Acceptable to some extent & - & & \\
\hline & & Unacceptable & - & & \\
\hline & \multirow[t]{3}{*}{ Taste } & Very desirable & $26(86.67 \%)$ & \multirow[t]{3}{*}{2.00} & \multirow{3}{*}{$\begin{array}{c}2.87 \\
\text { Very } \\
\text { desirable }\end{array}$} \\
\hline & & Desirable & $4(13.33 \%)$ & & \\
\hline & & Not desirable & - & & \\
\hline & \multirow[t]{3}{*}{ Smell } & Weak & - & \multirow[t]{3}{*}{2.00} & \multirow{3}{*}{$\begin{array}{l}1.03 \\
\text { Strong }\end{array}$} \\
\hline & & Average & $1(3.33 \%)$ & & \\
\hline & & Strong & $29(96.67 \%)$ & & \\
\hline & \multirow[t]{3}{*}{ Textures } & Solid & $1(3.33 \%)$ & \multirow[t]{3}{*}{2.00} & \multirow{3}{*}{$\begin{array}{c}2.03 \\
\text { Somewhat } \\
\text { coherent }\end{array}$} \\
\hline & & Somewhat coherent & $29(96.67 \%)$ & & \\
\hline & & Soft & - & & \\
\hline & \multirow{3}{*}{ Color } & Light & $5(16.67 \%)$ & \multirow[t]{3}{*}{2.00} & \multirow{3}{*}{$\begin{array}{c}2.17 \\
\text { Matched } \\
\text { with the } \\
\text { color of the } \\
\text { fruit used }\end{array}$} \\
\hline & & $\begin{array}{l}\text { Matched with the color of } \\
\text { the fruit used }\end{array}$ & $25(83.33 \%)$ & & \\
\hline & & Dark & - & & \\
\hline & \multirow{3}{*}{$\begin{array}{l}\text { The period } \\
\text { of validity }\end{array}$} & Such as product-ready & $30(100 \%)$ & \multirow[t]{3}{*}{2.00} & \multirow{3}{*}{$\begin{array}{l}3.00 \\
\text { Such as } \\
\text { product- } \\
\text { ready }\end{array}$} \\
\hline & & Less of the product-ready & - & & \\
\hline & & $\begin{array}{l}\text { Longer than the product- } \\
\text { ready }\end{array}$ & - & & \\
\hline
\end{tabular}


مجلة بحوث التربية النوعية - العلدد الخامس والعشرون - أبريل r r r r r

Table (7): Sensory evaluation for the consumers of the quality attributes of a food product (Pomegranate Juice) made from the trainees after the training courses:

\begin{tabular}{|c|c|c|c|c|c|}
\hline \multirow{4}{*}{\begin{tabular}{||l}
\multicolumn{1}{|c|}{$\begin{array}{c}\text { The } \\
\text { Products }\end{array}$} \\
$\begin{array}{l}\text { Pomgranate } \\
\text { Juice }\end{array}$
\end{tabular}} & \multicolumn{3}{|c|}{ Evaluation Description } & \multirow{2}{*}{$\begin{array}{c}\text { Mean } \\
\text { standard }\end{array}$} & \multirow[t]{2}{*}{ Mean answer } \\
\hline & & & $\mathrm{N}=\mathbf{3 0}$ & & \\
\hline & \multirow{2}{*}{$\begin{array}{l}\text { General } \\
\text { appearance }\end{array}$} & Homogeneous & $28(93.33 \%)$ & \multirow{2}{*}{1.50} & \multirow{2}{*}{$\begin{array}{c}1.93 \\
\text { Homogeneous }\end{array}$} \\
\hline & & Disproportionate & $2(6.67 \%)$ & & \\
\hline & \multirow[t]{3}{*}{ Taste } & Very desirable & $26(86.67 \%)$ & \multirow{3}{*}{2.00} & \multirow{3}{*}{$\begin{array}{c}2.83 \\
\text { Very } \\
\text { desirable }\end{array}$} \\
\hline & & Desirable & $3(10.0 \%)$ & & \\
\hline & & Not desirable & $1(3.33 \%)$ & & \\
\hline & \multirow[t]{3}{*}{ Smell } & Weak & $2(6.67 \%)$ & \multirow{3}{*}{2.00} & \multirow{3}{*}{$\begin{array}{c}1.04 \\
\text { Strong }\end{array}$} \\
\hline & & \begin{tabular}{|l|} 
Average \\
\end{tabular} & $8(26.67 \%)$ & & \\
\hline & & Strong & $20(66.67 \%)$ & & \\
\hline & \multirow{3}{*}{$\begin{array}{l}\text { The } \\
\text { phenomenon of } \\
\text { leaching }\end{array}$} & Yes & - & \multirow{3}{*}{2.00} & \multirow{3}{*}{$\begin{array}{c}1.06 \\
\text { No }\end{array}$} \\
\hline & & Rather & $4(13.33 \%)$ & & \\
\hline & & No & $26(86.67 \%)$ & & \\
\hline & \multirow{2}{*}{ Color } & Red Light & $5(16.67 \%)$ & \multirow{2}{*}{1.50} & \multirow{2}{*}{$\begin{array}{c}1.67 \\
\text { Dark Red }\end{array}$} \\
\hline & & Dark Red & $25(83.33 \%)$ & & \\
\hline & \multirow[t]{3}{*}{$\begin{array}{l}\text { The period of } \\
\text { validity }\end{array}$} & $\begin{array}{l}\text { Such as product- } \\
\text { ready }\end{array}$ & $4(13.33 \%)$ & \multirow{3}{*}{2.00} & \multirow{3}{*}{$\begin{array}{c}2.13 \\
\text { Less of the } \\
\text { product- } \\
\text { ready }\end{array}$} \\
\hline & & $\begin{array}{l}\text { Less of the product- } \\
\text { ready }\end{array}$ & $26(86.67 \%)$ & & \\
\hline & & $\begin{array}{l}\text { Longer than the } \\
\text { product- ready }\end{array}$ & - & & \\
\hline
\end{tabular}


The Effectiveness of a Training Courses for Developing the Productive Capacities

Table (8): Sensory evaluation for the consumers of the quality attributes of a food product (Orange Juice) made from the trainees after the training courses:

\begin{tabular}{|c|c|c|c|c|c|}
\hline The Product & \multicolumn{3}{|c|}{ Evaluation Description } & \multirow{2}{*}{$\begin{array}{c}\text { Mean } \\
\text { standard }\end{array}$} & \multirow[t]{2}{*}{ Mean answer } \\
\hline \multirow{3}{*}{ Orange Juice } & & & & & \\
\hline & \multirow{2}{*}{ General appearance } & \multirow{2}{*}{\begin{tabular}{|l|} 
Homogeneous \\
Disproportionate \\
\end{tabular}} & \multirow{2}{*}{\begin{tabular}{|c|}
$27(90.0 \%)$ \\
$3(10.0 \%)$
\end{tabular}} & \multirow[t]{2}{*}{1.50} & \multirow{2}{*}{$\begin{array}{c}1.90 \\
\text { Homogeneous }\end{array}$} \\
\hline & & & & & \\
\hline & Taste & Very desirable & $27(90.0 \%)$ & 2.00 & 2.57 \\
\hline & & Desirable & $3(10.0 \%)$ & & Very desirable \\
\hline & & Not desirable & - & & \\
\hline & Smell & Weak & - & 2.00 & 1.27 \\
\hline & & Average & $8(26.67 \%)$ & & Strong \\
\hline & & Strong & $22(73.33 \%)$ & & \\
\hline & & Yes & $1(3.33 \%)$ & 2.00 & 1.02 \\
\hline & The phenomenon of & Rather & $4(13.33 \%)$ & & No \\
\hline & leaching & No & $25(83.33 \%)$ & & \\
\hline & & Orange Light & $3(10.0 \%)$ & 1.50 & 1.10 \\
\hline & Color & Dark Orange & $27(90.0 \%)$ & & Dark Orange \\
\hline & The period of validity & $\begin{array}{l}\text { Such as product- } \\
\text { ready }\end{array}$ & $4(13.33 \%)$ & 2.00 & $\begin{array}{c}2.13 \\
\text { Less of the }\end{array}$ \\
\hline & & $\begin{array}{l}\text { Less of the } \\
\text { product-ready }\end{array}$ & $26(86.67 \%)$ & & product-ready \\
\hline & & $\begin{array}{l}\text { Longer than the } \\
\text { product- ready }\end{array}$ & - & & \\
\hline
\end{tabular}

Table (8): Represents sensory evaluation for the consumers of the quality attributes of a food product orange juice made from the trainees after the training courses. It could be seen that $(90.0 \%)$ of the consumers evaluated the general appearance that is homogeneous. The taste was very desirable by $(90.0 \%)$ of the consumers. Regarding the smell was strong by $(73.33 \%)$ of the consumers. Concerning the phenomenon of leaching were not found by $(83.33 \%)$ of the consumers. The color was dark orange by $(90.0 \%)$ of the consumers. The period of validity was less of the product-ready by $(86.67 \%)$ of the consumers.

Table (9): Shows sensory evaluation for the consumers of the quality attributes of a food product okra freezing made from the trainees after the training courses. It was clear that the general appearance was very acceptable by $(76.67 \%)$ of the consumers. Also, the taste was very desirable by $(76.67 \%)$ of the consumers. According to the color was normal green by $(80.0 \%)$ of the consumers. The period of validity was such as product-ready by $(66.67 \%)$ of the consumers. 
Table (9): Sensory evaluation for the consumers of the quality attributes of a food product (Okra freezing) made from the trainees after the training courses:

\begin{tabular}{|c|c|c|c|c|c|}
\hline The Product & \multicolumn{3}{|c|}{ Evaluation Description } & \multirow{2}{*}{$\begin{array}{c}\text { Mean } \\
\text { standard }\end{array}$} & \multirow{2}{*}{$\begin{array}{c}\text { Mean } \\
\text { answer }\end{array}$} \\
\hline & & & $\mathbf{N}=\mathbf{3 0}$ & & \\
\hline \multirow{13}{*}{ Okra freezing } & \multirow{4}{*}{$\begin{array}{l}\text { General } \\
\text { appearance }\end{array}$} & Very acceptable & $23(76.67 \%)$ & \multirow[t]{4}{*}{2.50} & \multirow{4}{*}{$\begin{array}{c}3.70 \\
\text { Very } \\
\text { acceptable }\end{array}$} \\
\hline & & Acceptable & $5(16.67 \%)$ & & \\
\hline & & Acceptable to some extent & $2(6.67 \%)$ & & \\
\hline & & Unacceptable & - & & \\
\hline & \multirow[t]{3}{*}{ Taste } & Very desirable & $23(76.67 \%)$ & \multirow[t]{3}{*}{2.00} & \multirow{3}{*}{$\begin{array}{c}2.77 \\
\text { Very } \\
\text { desirable }\end{array}$} \\
\hline & & Desirable & $7(23.33 \%)$ & & \\
\hline & & Not desirable & - & & \\
\hline & \multirow{3}{*}{ Color } & Light Green & - & \multirow{3}{*}{2.00} & \multirow{3}{*}{$\begin{array}{c}1.20 \\
\text { Normal } \\
\text { Green }\end{array}$} \\
\hline & & Dark Green & $6(20.0 \%)$ & & \\
\hline & & Normal Green & $24(80.0 \%)$ & & \\
\hline & \multirow{3}{*}{$\begin{array}{l}\text { The period } \\
\text { of validity }\end{array}$} & Such as product-ready & $20(66.67 \%)$ & \multirow[t]{3}{*}{2.00} & \multirow{3}{*}{$\begin{array}{c}2.60 \\
\text { Such as } \\
\text { product- } \\
\text { ready }\end{array}$} \\
\hline & & Less of the product-ready & $8(30.0 \%)$ & & \\
\hline & & $\begin{array}{l}\text { Longer than the product- } \\
\text { ready }\end{array}$ & $2(3.33 \%)$ & & \\
\hline
\end{tabular}

Table (10): Shows sensory evaluation for the consumers of the quality attributes of a food product ppomegranate freezing made from the trainees after the training courses. It could be noticed that $(73.33 \%)$ of the consumers evaluated the general appearance that is very acceptable. Regarding the taste was very desirable by $(76.67 \%)$ of the consumers. Also, the color was matched with the color of pomegranate used by $(76.67 \%)$ of the consumers. The period of validity was 6 Months by $(80.0 \%)$ of the consumers.

Table (10): Sensory evaluation for the consumers of the quality attributes of a food product (Pomegranate freezing) made from the trainees after the training courses: 


\begin{tabular}{|c|c|c|c|c|c|}
\hline The & & Evaluation Description & & Mean & Mean \\
\hline & & & $\mathrm{N}=\mathbf{3 0}$ & & \\
\hline Pomegrana & General & Very acceptable & $22(73.33 \%)$ & 2.50 & \\
\hline & appearance & Acceptable & $6(20.0 \%)$ & & Very \\
\hline & & Acceptable to some extent & $2(6.67 \%)$ & & \\
\hline & & Unacceptable & - & & \\
\hline & Taste & Very desirable & $23(76.67 \%)$ & 2.00 & \\
\hline & & \begin{tabular}{|l|} 
Desirable \\
\end{tabular} & $7(23.33 \%)$ & & desirable \\
\hline & & \begin{tabular}{|l|} 
Not desirable \\
\end{tabular} & - & & \\
\hline & Color & $\begin{array}{l}\text { Matched with the color of } \\
\text { pomegranate used }\end{array}$ & $23(76.67 \%)$ & 2.00 & $\begin{array}{c}2.63 \\
\text { Matched }\end{array}$ \\
\hline & & $\begin{array}{l}\text { Lighter than the color of } \\
\text { pomegranate used }\end{array}$ & $3(10.0 \%)$ & & $\begin{array}{l}\text { with the } \\
\text { color of }\end{array}$ \\
\hline & & $\begin{array}{l}\text { Darker than the color of } \\
\text { pomegranate used }\end{array}$ & $4(13.33 \%)$ & & $\begin{array}{l}\text { pomegranat } \\
\text { e used }\end{array}$ \\
\hline & The period & $\square 6$ Months & $24(80.0 \%)$ & 1.50 & 1.80 \\
\hline & & $\geq 6$ Months & $6(20.0 \%)$ & & 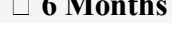 \\
\hline
\end{tabular}


Table (11): Sensory evaluation for the consumers of the quality attributes of a food product (Tomato Sauce) made from the trainees after the training courses:

\begin{tabular}{|c|c|c|c|c|c|}
\hline \begin{tabular}{|l|} 
The Product \\
\end{tabular} & \multicolumn{3}{|c|}{ Evaluation Description } & \multirow{2}{*}{$\begin{array}{c}\text { Mean } \\
\text { standard }\end{array}$} & \multirow[t]{2}{*}{ Mean answer } \\
\hline \multirow[t]{18}{*}{ Tomato Sauce } & & & $\mathrm{N}=\mathbf{3 0}$ & & \\
\hline & \multirow{4}{*}{\begin{tabular}{|l|} 
General \\
appearance
\end{tabular}} & Very acceptable & $23(76.67 \%)$ & \multirow[t]{4}{*}{2.50} & \multirow{4}{*}{$\begin{array}{c}3.70 \\
\text { Very } \\
\text { acceptable }\end{array}$} \\
\hline & & Acceptable & $5(16.67 \%)$ & & \\
\hline & & \begin{tabular}{|l|}
$\begin{array}{l}\text { Acceptable to some } \\
\text { extent }\end{array}$ \\
\end{tabular} & $2(6.67 \%)$ & & \\
\hline & & Unacceptable & - & & \\
\hline & \multirow[t]{2}{*}{ Taste } & Bitter taste & $29(96.67 \%)$ & \multirow[t]{2}{*}{1.50} & \multirow{2}{*}{$\begin{array}{c}1.97 \\
\text { Bitter taste }\end{array}$} \\
\hline & & Sweet & $1(3.33 \%)$ & & \\
\hline & \multirow[t]{3}{*}{ Smell } & Weak & $2(6.67 \%)$ & \multirow[t]{3}{*}{2.00} & \multirow{3}{*}{$\begin{array}{c}1.97 \\
\text { Average }\end{array}$} \\
\hline & & Average & $25(83.33 \%)$ & & \\
\hline & & Strong & $3(10.0 \%)$ & & \\
\hline & \multirow{3}{*}{ Textures } & Solid & $17(56.67 \%)$ & \multirow[t]{3}{*}{2.00} & \multirow{3}{*}{$\begin{array}{l}2.57 \\
\text { Solid }\end{array}$} \\
\hline & & Somewhat coherent & $13(43.33 \%)$ & & \\
\hline & & Soft & - & & \\
\hline & \multirow[t]{2}{*}{ Color } & Red Light & \begin{tabular}{|l|}
$7(23.33 \%)$ \\
\end{tabular} & \multirow[t]{2}{*}{1.50} & \multirow{2}{*}{$\begin{array}{c}1.23 \\
\text { Dark Red }\end{array}$} \\
\hline & & Dark Red & $23(76.67 \%)$ & & \\
\hline & \multirow{3}{*}{$\begin{array}{l}\text { The period } \\
\text { of validity }\end{array}$} & Such as product-ready & $6(20.0 \%)$ & \multirow[t]{3}{*}{2.00} & \multirow{3}{*}{$\begin{array}{c}2.20 \\
\text { Less of the } \\
\text { product-ready }\end{array}$} \\
\hline & & $\begin{array}{l}\text { Less of the product- } \\
\text { ready }\end{array}$ & $24(80.0 \%)$ & & \\
\hline & & $\begin{array}{l}\text { Longer than the } \\
\text { product- ready }\end{array}$ & - & & \\
\hline
\end{tabular}

Table (11): Represents sensory evaluation for the consumers of the quality attributes of a food product ttomato sauce) made from the trainees after the training courses. It was clear that the general appearance was very acceptable by $(76.67 \%)$ of the consumers. Regarding the taste was bitter taste by $(96.67 \%)$ of the consumers. The smell was average by $(83.33 \%)$ of the consumers. $(56.67 \%)$ of the consumers evaluated the textures that is solid. Concerning the color was dark red by $(76.67 \%)$ of the consumers. The period of validity was less of the product-ready by $(80.0 \%)$ of the consumers.

\section{Discussion:}

The small-scale industries play an important role in the national economy of many advanced and developing countries and the economic and social analysis indicate the development of international experience in this field but some Asian countries have made tremendous achievements during the last two decades and turned from the forces of consumer power to be 
productive creative resort to the small producer and small industries that fit with their own investments, through the exploitation of raw materials available and devise new methods of implementation consistent with the abundance of labor to produce goods linked to the daily lives of citizens like food and textiles industries (Richard J. ,2000\& Ibrahim H., 2005).

Training is the voltage regulator planned which aims to provide workers with the knowledge, skills and new behavioral patterns as well as their knowledge, skills, and modifies their behavior patterns at work (Alselmy, 1992).

The jam of the methods of keeping fruit turning to food products not subject to corruption (Lang\& Jenifer H., 1998). Fruit juice is a drink of fruit and make juice from fresh fruit that we get squeezing fruit and filter the juice and save transaction thermal where is poured in a special container shall be boiled for a short period and during that add to it a sufficient quantity and appropriate when it was melting the amount of sugar taken the juice boiled and cooled and filtered by filters and packed in special containers or bottles especially.

The process of freezing food is to rid this article from the heat and give this heat to another substance and the delivery of food material to be saved to a temperature low does not allow active growth and multiplication factors of corruption of bacteria, fungi and yeasts do not allow active enzymes or other chemical reactions. The idea industry of tomato sauce concentration on the sauce solids to about $25 \%$ and add salt and preservative and color turned to dark red (Hussein T., 2007).

The present study showed that the training courses included 36 girls and women trainees. This disagree with (Russell S.\& Taylor B. 1998) who stated that the concept of small-scale project is a project that does not depend on technology-intensive in general, Sahara is the basis for its number of workers no more than five members of the maximum capital of ten thousand to fifteen thousand pounds. But we can consider this project medium project. This coincides with (Fathi Z., 2006) who reported that the project, which accommodate a number of workers from the worker to four workers on that project infinitely small and the project, which accommodate from five workers to fourteen working as a small project. The project, which accommodate from fifteen workers to forty-nine factor as a medium $\mathrm{n}$ and more than that is a big project.

The mean age of trainees was 27.5 years which could explain that young people is more careful and turning to small and medium projects and 
training courses. This agrees with (Heikal M., 2003) who mentioned that the small-scale industries are those engaged in small enterprises each of which works a few of the exploiters and the activity of industrial activities as defined as the activity that has a specific purpose, time and specific resources: the small size of the project compared to the big project and providing job opportunities for young people to eliminate unemployment.

Regarding education level, it is noticed that the trainees whose education level is secondary want to take training courses for food industrial than those education level is high and basic. Concerning occupation, the highest percentage in the girls and women trainees was unemployed (housewives). A highest percentage of trainees $(58.33 \%)$, their social status were single. All trainees were in rural areas. This may be due to difficult life people have. Regarding number of home equipments, the highest percentage of trainees $(92.0 \%)$ has $\leq$ basic home equipments which were considered of low socioeconomic class.

The present study showed that knowing the trainees methods of manufacture jams, juices, tomato sauce and keeping of fruits and vegetables by freezing was significantly post training courses at ( $\mathrm{p} \rrbracket \quad 0.001$ ).

This result agrees with (Diab A., 1997) who indicated that the training program aims to improve the skills and inform individuals Goals training is derived from the training requirements if the latter is accurate, clear and well-defined reflect the situation practical fact, and the training objectives are also clear and specific, achievable. Also, Abdel Wahab A.\& Khattab A., (1997) reported that the training and means of scientific and practical aims to raise the efficiency of the human element through the refinement of his skills and abilities of any training is a comprehensive process both sides of the theoretical and practical.

Dealing with using ready-made jams, juice, vegetables and fruits frozen and tomato sauce was significantly at ( $\mathrm{p} \rrbracket \quad 0.001, \mathrm{p} \rrbracket \quad 0.01, \mathrm{p} \rrbracket \quad 0.05, \mathrm{p} \rrbracket \quad 0.01)$ respectively. Also, concerning making a jam, fresh juices, vegetables and fruits by freezing and tomato sauce methods was significantly post training courses at ( $\mathrm{p}$ 0 0.001). which agrees with (Rodney E. et al., 2004) who reported that the activities such as workshop and other ongoing advanced training courses can contribute to strengthening the capability of the participants where Participants reported that their understanding of and ability to perform improved as a result of attending the course.

The present study indicates that the general appearance of fig, carrot and orange jams are acceptable by the consumers, the taste of fig and orange jam 
is very desirable while carrot jam is desirable. Concerning the smell of three kinds of jam is strong and the textures are somewhat coherent. Regarding the color of the three kinds of jam is matched with the color of the fruit used. The period of validity of three kinds of jam is such as product-ready by the consumers. Which indicates that the specifications of the three resulting good jam in appearance, taste, smell, texture, color, period. This may be due to control amounts of sugar and acid and the degree of settlement. This result is in agreement with (Emmanuel O. A., et al., 2006) who reported that though sugar, pectin and acid are essential in jam making, the effect of these ingredients balancing is significant on the quality characteristics of the final product. A sugar concentration of at least $50 \%$, with the addition of $0.5 \%$ pectin with $\mathrm{pH}$ levels between 3.2 and 3.5 would produce a jam of acceptable color, spread ability, gel set and good taste as well.

Dealing with pomegranate and orange juice, the general appearance is homogeneous by consumers the taste is very desirable, while the smell is strong. This may be due to suspended solids, which agrees with (Barbara R. et al., 2004) who reported that the role of suspended solids in sensorial perception and flavor release in orange juice, where the amount and the size of the suspended solids critically modified not only the texture perception but also the odor and the overall flavor perception, including the "freshly squeezed" and the "artificial flavor" descriptors.

The phenomenon of leaching does not exist. This may be due to that the juices prepared by the heated way. This is coincides with (Saad S. A., et al., 1995) who reported that thpreparing drink by heated way does not show the phenomenon of leaching because of the destruction of enzymes by heat, where the heat collects the foreign and proteins substances on the surface in the form of foam and it is removed and this leads to lack of precipitation during storage and therefore not a phenomenon of leaching.

The color of pomegranate and orange juice is dark according to type of fruit. Which explain that the color of the juice did not differ from the color of the fruit used. This result is in agreement with ((Saad S. A., et al., 1995) who shows that Color heated drink is affected slightly during heating does not change color after a drink in storage for the destruction of enzymes by heat.

Also, this agrees with (Jiao B. et al., 2004) who concluded that fruit juices have been traditionally concentrated by multi-stage vacuum evaporation, resulting in a loss of fresh juice flavors, color degradation and a "cooked" taste due to the thermal effects. 
The period of validity to pomegranate and orange juice is less of the product-ready by the consumers. This may be due to the lack of sterilization conditions necessary for the manufacture of juices and that the limited financial resources. This agrees with (Saad S. A., et al., 1995) who mentioned that fermentation of the juice may be due to the pasteurization procedure incorrectly (in this research did not used to lack of pasteurization devices), or contamination of the raw materials used in the industry heavy pollution.

This sensory evaluation of juices was by ordinary consumers, not experts. Meaning that can be the difference in evaluation. This agrees with (Hely T.\& Armand V., 2002) Who reported that in adult US subjects $(\mathrm{n}=78)$ tasted and rated three juice samples, the consumption of a functional food will be inversely related to the severity of off-flavor and to the required frequency and duration of consumption.

(Dante G. et al., 2006) reported that in a panel of 20 to 27 screened judges was used to determine the threshold of pure limonin and naringin, individual thresholds showed a wide range of sensitivity to both limonin and naringin bitterness.

Also, the present study shows that the general appearance of okra and pomegranate freezing is very acceptable by consumers and the taste is very desirable. While the color of okra freezing is normal green but in pomegranate freezing is matched with the color of pomegranate used. According to the period of validity of okra freezing is such as productready, while in pomegranate freezing is 46 Months. This is probably due to bad storage temperature or freezing, or perhaps due to contain pomegranate grains a high rate of moisture. This agrees with (Mohammed M. et al., 2011) who reported in leafy vegetables that the sensory attributes of leafy vegetables during 180 days of frozen storage were affected mainly by freezing temperature rather than frozen storage time. Also, Stover E.\& Mercure E. (2007) reported that each seed has a surrounding water-laden pulp - the edible aril-ranging in color from white to deep red or purple. The seeds are embedded in a white, spongy, astringent pulp

Also, this result is in agreement with (Redmond G. et al., 2002) concluded that lowering the freezing temperatureo,reduced the time required for freezing, gave a softer product and led to a reduction in drip loss. Freezechilling resulted in a firmer product and a higher drip loss compared to chilling alone. There was no difference in vitamin $\mathrm{C}$ content or in taste panel acceptability between the chilled and the freeze-chilled products. 
(O'Leary E. et al., 2000) indicated that freeze-chilling reduced the vitamin C content of instant mashed potato and steamed broccoli in comparison with frozen-only or freshly prepared. Also, Wang H. et al., (2007) mentioned the initial freezing points varied from -0.1 to $-2.7{ }^{\circ} \mathrm{C}$. The end-points of freezing were all below $-20.0{ }^{\circ} \mathrm{C}$. With a cryomicroscope, the sizes of ice crystals in frozen vegetable saps were found to decrease from 26 to $3 \mu \mathrm{m}$ when the freezing rates increased from 1.0 to $10.0{ }^{\circ} \mathrm{C} / \mathrm{min}$.

Also, the general appearance of tomato sauce is very acceptable, the taste is bitter taste, the smell is average and the texture is solid. The color of tomato sauce is dark red by consumers. Finally the period of validity is less of the product- ready. This is probably due to the lack of sufficiently sterilization of the lack of special equipment so the high prices or may be due to mobilize the sauce in the pots is not dry or open containers and exposed to the atmosphere (Hamayel A. F. 1991).

\section{Conclusion:}

The present research indicates that the effectiveness of training courses for developing the productive capacities in the field of Food Industries for the women and girls in Refa and Albadary villages at Assiut governorate, to serve the small projects. And improve the gained knowledge and skills to the trainees after the training courses.

\section{Recommendations:}

1- Necessity of continuing training for women and girls in the villages at intervals in order to exploit the surplus of agricultural crops in the season and the manufacture of food products, where this is deemed an essential element of human development to cope with rapid changes.

2- Development of training courses in pursuit all that is new in field the food industries and applied to food products manufacturer.

\section{References:}

Abdel Aziz R. I. (2001): "Assessment of business environment and its impact on the management and development of small industries on the application of small industries in the garment business," Master Thesis, Faculty of Commerce and Business Administration, University of Helwan.

Abdel-Wahab. A, Khattab A. (1997): "Human resources management", Faculty of Commerce, Ain Shams University. 
Alselmy A. (1992): "Human resources management", Alghareb Library, Cairo.

Barbara R., Nicole F., Sophie N., and Elisabeth G. (2004): Role of Pulp in Flavor Release and Sensory Perception in Orange Juice. $J$. Agric. Food Chem.; 52(13), pp 4204-4212.

Dante G. G., Vincent P. M., Jean G. T. (2006): Effect of some citrus juice constituents on taste thresholds for limonin and naringin bitterness. Journal of the Science of Food and Agriculture; 24(10), pp 1277-1288, October 1973. Article first published online: 9 MAY 2006.

Diab A. (1997): "Human resources management", School of Business, University of Cairo.

Emmanuel O. A., Dorinda N., Joseph A., and George A. (2006):"Effect of Sugar, Pectin and Acid Balance on the Quality Characteristics of Pineapple (Ananas Comosus) Jam." Proceeding of the 13th World Food Congress. . Nantes, France, pp 1405-1406, September 17-21.

Fathi Z. (2006): "the aesthetic values of art, colorful embroidery and its role in enriching the small industries, embroidered," Unpublished Master Thesis, Faculty of Home Economics, Helwan University.

Gomaa E. (2007): Domestic food processing light. The first part. The first edition. Dar Alwafaa for printing and publishing.

Hamayel A. F. (1991): food industries (the most recent methods for the manufacture, packing, drying and preservation of vegetables and perfume extraction) - Dar Ibn Siena.

Heikal M. (2003): small business management skills, a collection of Egyptian Nile.

Hely T. \& Armand V. (2002): Consumer responses to an off-flavor in juice in the presence of specific health claims. Food Quality and Preference; 13 (7-8), October-December, pp 561-569.

Hussein T. (2007): "Preservation techniques and storage of plant products Vegetables - Fruits Grains - Olive". Dar Alaa Aladdin Suria Damask, Second Edition.

Ibrahim H.S. (2005): Management of small projects to Where? Publisher Library, Alameer of the distribution.

Jiao B., Cassano A. and Drioli E. (2004): Recent advances on membrane processes for the concentration of fruit juices. Journal of Food Engineering; 63(3), August, pp 303-324. 
The Effectiveness of a Training Courses for Developing the Productive Capacities $=$

Lang\& Jenifer Harvey. (1998): Larousse Gastronomique. New York: Crown.

Mohammed M., Koushki M. R., Ahmadian F. S. and Moslemy M. (2011): The impact of home freezing on the sensory characteristics of ready-to-use leafy vegetables. Journal of the Science of Food and Agriculture; 91(3), pp 519-522, February.

O'Leary E., Gormley T.R., Butler F. and Shilton N. (2000): The Effect of Freeze-chilling on the Quality of Ready-meal Components. Food Science and Technology; 33(3), May, pp 217-224.

Redmond G.A., Butler F. and Gormley T.R. (2002): The Effect of Freezing Conditions on the Quality of Freeze-Chilled Reconstituted Mashed Potato. Received 22 June 2001; Accepted 9 October 2001. Available online 29 June 2002.

Richard J. L. (2000): Critical Path Method. The Engineering Handbook. Ed. Richard C. Dort Boca Raton CRC Press LLC.

Rodney E. R., MS, SV(ASCP); Karen Milwaukie, MA, MT(ASCP)SC; Marguerite Oates, MPA, CLS, SBB(ASCP) (2004): National Laboratory Training Network Public Health Series Course: Molecular Diagnostic Techniques for the Public Health Laboratory. Laboratory Medicine; 35(8).

Russell S. R.\& Taylor B. W. (1998): Operations management: Focusing on Quality and competitiveness. Prentice-Hall International, Inc.

Saad S. A., Mahmoud A. A. and Mohammed A. Z. (1995): food industries - the foundations of preservation and food manufacturing - Academic library - pp220-222.

Stover E and Mercure E. (2007): "The pomegranate: a new look at the fruit of paradise". HortScience 42 (5): 1088-92. August.

Vandallen (1994): Research methods analysis. Egyptian Anglo library, Cairo, Egypt. P292-343.

Wang H., Zhang S., Chen G. (2007): Experimental study on the freezing characteristics of four kinds of vegetables. Food Science and Technology; 40(6), August, pp 1112-1116. 


\section{الالخص العربهي:}

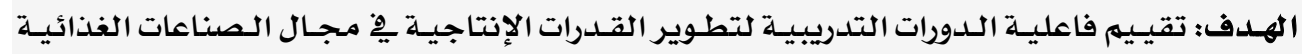
لنساء وفتيات قري ريفا والبداري بمحافظة أسيوط لخدمة المشاريع الصغيرة.

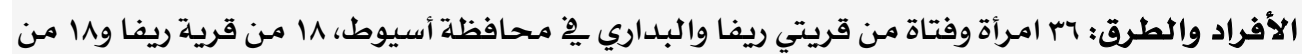

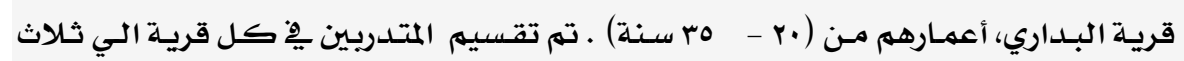

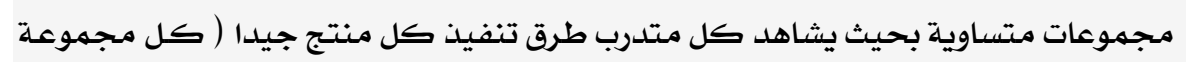

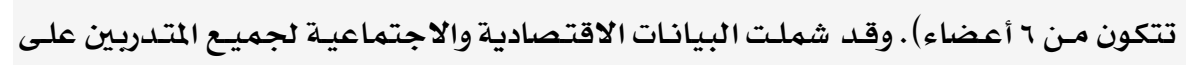

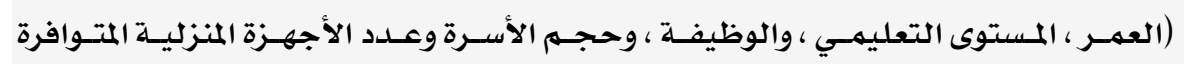

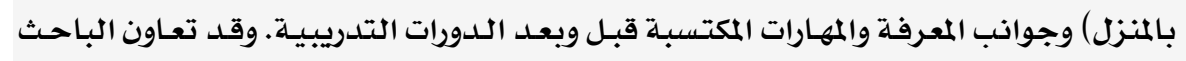
مـع فريق جايكا اليابانيـة ضـمن مشروع دراسـة الخطـة الرئيسية للتنميـة الريفيـة مـن خـلال

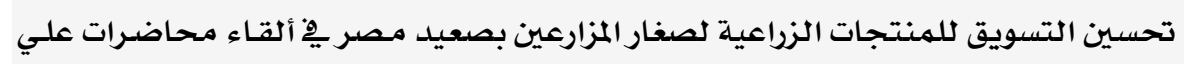

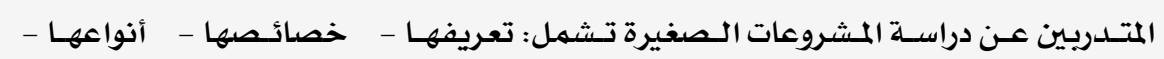

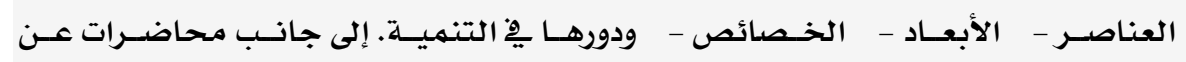

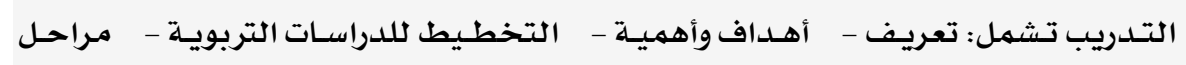

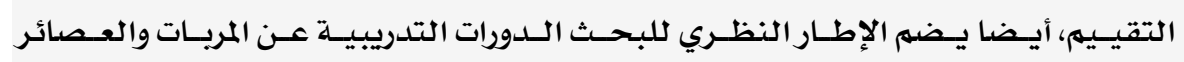

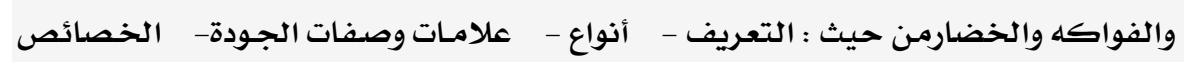

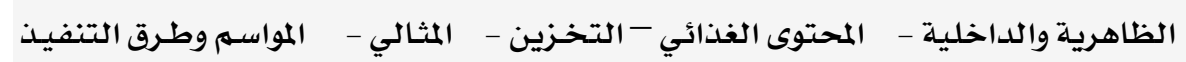

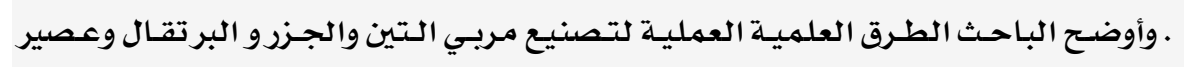

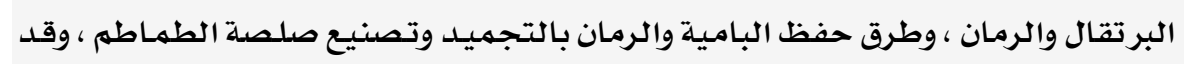

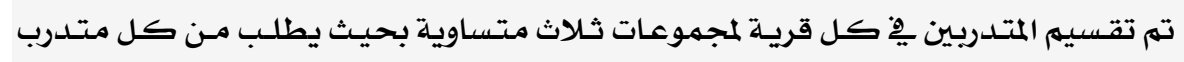

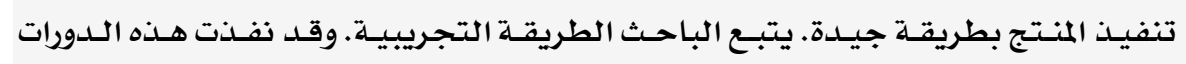

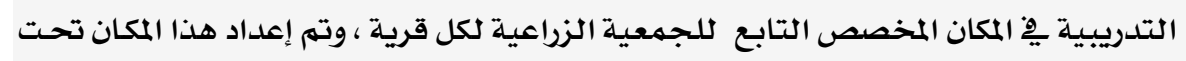

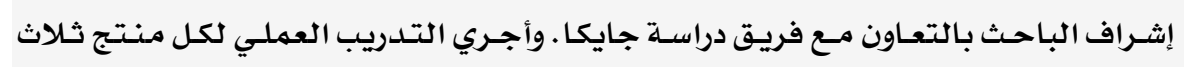

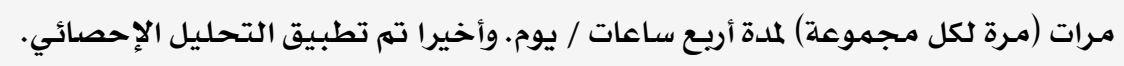

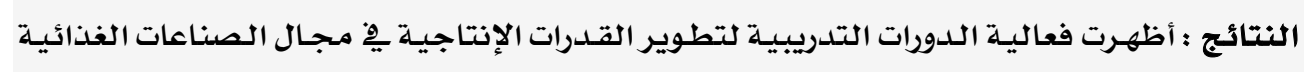

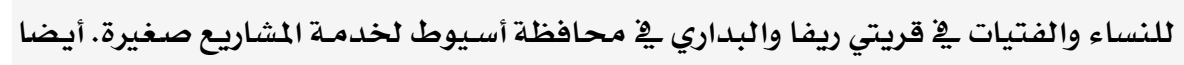

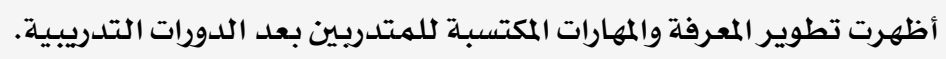

